\begin{tabular}{|l|l|l||}
\hline \multicolumn{2}{|c|}{ PublisherInfo } \\
\hline \hline PublisherName & $:$ & BioMed Central \\
\hline \hline PublisherLocation & $:$ & London \\
\hline \hline PublisherImprintName & $:$ & BioMed Central \\
\hline \hline
\end{tabular}

\title{
Characterisation of LST1
}

\begin{tabular}{|l|l|l||}
\hline \multicolumn{2}{|c||}{ ArticleInfo } \\
\hline \hline ArticleID & $:$ & 6 \\
\hline \hline ArticleDOI & $:$ & $10.1186 /$ ar-2000-66816 \\
\hline \hline ArticleCitationID & $:$ & 66816 \\
\hline \hline ArticleSequenceNumber & $:$ & 2 \\
\hline \hline ArticleCategory & $:$ & Paper Report \\
\hline ArticleFirstPage & $:$ & 1 \\
\hline ArticleLastPage & $:$ & 3 \\
\hline \hline & & RegistrationDate : 2000-5-31 \\
ArticleHistory & $:$ & OnlineDate \\
\hline \hline ArticleCopyright & $:$ & Current Science Ltd2000-51 \\
\hline \hline ArticleGrants & $:$ & \\
\hline \hline ArticleContext & $:$ & 130752211 \\
\hline \hline
\end{tabular}


Gerry Wilson, ${ }^{\text {Aff1 }}$

Aff1 Royal Hallamshire Hospital, Sheffield, USA

\section{Keywords}

Expression, LST1, MHC, TNF

\section{Context}

The LST1 gene was recently identified in the TNF locus within the class III region of the MHC. This region has been shown to be genetically associated with susceptibility to, or with the severity of, a large number of diseases that have a significant inflammatory component. Although much evidence has implicated polymorphism within the TNF promoter, there is the possibility that these associations may reflect linkage disequilibrium with polymorphism in a nearby gene. It is therefore important to identify all potential immunomodulating genes within this region. To determine the pattern of expression of the LST1 gene and the biological functions of the encoded proteins.

\section{Significant findings}

Four different LST1 splice variants were detected in $\mathrm{CD} 14^{+}$cells. Constitutive expression was also found in $\mathrm{CD}^{+}, \mathrm{CD}^{+}$and $\mathrm{CD} 19^{+}$cells and in dendritic cells. This pattern was not changed by stimulation of freshly isolated cells by a range of cytokines and mitogens. Sequencing of the transcripts revealed extensive alternative splicing with seven variants in PBMC (14 in various tissues). Cell surface expression was detected on two monocytic cell lines. Exon 3 encoded a hydrophobic 23 amino acid transmembrane domain which was encoded in only two transcripts, the other five transcripts probably being secreted proteins. Exon 4 encoded 23 nucleotides leading to a frame shift in the carboxy-terminal end of the protein and was contained in three transcripts. Two isoforms, different in the extracellular domains, both displayed marked inhibitory effects on lymphocyte proliferation.

\section{Comments}


It is of interest that a novel gene with these biological activities should be isolated in a region $9 \mathrm{~kb}$ centromeric of tumour necrosis factor (TNF) and $4 \mathrm{~kb}$ telomeric of LT. In view of the many genetic associations of this region with human diseases, this is probably one of the most extensively studied regions of the genome. The identification and characterisation of LST1 highlights the complexity of unravelling the genetic determinants in polygenic diseases. This gene will undoubtedly interest many groups who are investigating the association of the MHC with these diseases.

\section{Methods}

Peripheral blood mononuclear cells (PBMC) were isolated and different cell populations separated by FACS. The cells were stimulated using a range of cytokines and mitogens. Following culture RNA was isolated and expression of LST1 isoforms was assessed by RT-PCR; differently sized products were identified and sequenced. Antibodies to LST1 were raised in rabbits and used to determine cell surface expression patterns. Two of the isoforms were produced in a bacterial expression system and were used in lymphocyte proliferation assays following phytohaemagglutinin and candidin stimulation. The effects of recombinant LST1 isoforms were also assessed in the mixed lymphocyte reaction.

\section{References}

1. Rollinger-Holzinger I, Eibl B, Pauly M, Griesser U, Hentges F, Auer B, Pall G, Schratzberger P, Niederwieser D, Weiss EH, Zwierzina H: LST1: a gene with extensive alternative splicing and immunomodulating function. J Immunol. 2000, 164: 3169-3176.

This PDF file was created after publication. 